\title{
Implementasi Kebijakan Ketenagakerjaan \\ Tentang Bursa Kerja Di Dinas Tenaga Kerja \\ Kota Sukabumi
}

\author{
Implementation of Manpower Policy
}

About the Job Fair at the Manpower Office

Sukabumi City

\author{
Najwa Nursyariyah, Tuah Nur, Dine Meigawati \\ Program Studi Administrasi Publik, Fakultas llmu Administrasi dan Humaniora, \\ Universitas Muhammadiyah Sukabumi \\ email: nursnazwa@gmail.com
}

\begin{abstract}
Abstrak
Implementasi Kebijakan Ketenagakerjaan Tentang Bursa Kerja di Dinas Tenaga Kerja Kota Sukabumi. Tujuan dari penelitian ini untuk mengetahui bagaimana implementasi kebijakan ketenagakerjaan tentang bursa kerja dalam upaya mengurangi angka pengangguran di Dinas Tenaga Kerja Kota Sukabumi. Metode penelitan yang digunakan dalam penelitian ini adalah pendekatan kualitatif, penelitian yang dilakukan bersifat deskriptif yang menggambarkan fenomena yang bersifat nyata dengan apa yang terjadi di lapangan. Penelitian ini menggunakan empat variabel implementasi kebijakan dari George Edward meliputi komunikasi, sumber daya manusia, disposisi dan struktur birokrasi. Dari hasil penelitian dapat diperoleh kesimpulan bahwa implementasi kebijakan sudah berjalan dengan baik jika dilihat dari sisi disposisi dan struktur birokrasi. Namun dari sisi komunikasi dan sumber daya manusia sudah dilaksanakan tetapi belum optimal. Hal tersebut dapat menghambat keberhasilan dari pelaksanaan bursa kerja di Dinas Tenaga Kerja Kota Sukabumi dan perlu mendapat perhatian lebih penting dari pemerintah untuk kedepannya dalam pelaksanaan kebijakan bursa kerja.
\end{abstract}

Kata Kunci: implementasi; kebijakan; bursa kerja

\begin{abstract}
Implementation of Manpower Policy on the Job Market at the Sukabumi City Manpower Office. The purpose of this study is to find out how the implementation of employment policies on the labor market in an effort to reduce unemployment in the Sukabumi City Labor Office. The research method used in this study is a qualitative approach, the research conducted is descriptive in nature which describes real phenomena that occur in the field. This study uses four policy implementation variables from George Edward including communication, human resources, disposition and bureaucratic structure. From the results of the study it can be concluded that the implementation of the policy has been going well when viewed from the disposition and bureaucratic structure. But in terms of communication and human resources have been implemented but not yet optimal. This can hamper the success of the implementation of the labor market at the Sukabumi City Labor Office and needs to get more important attention from the government in the future in implementing labor market policies.
\end{abstract}

Keywords: implementation; policy; job fair 


\section{Pendahuluan}

Angka pengangguran di Kota Sukabumi setiap tahun bertambah seiring dengan bertambahnya jumlah lulusan sekolah, baik sekolah dasar, sekolah menengah maupun lulusan perguruan tinggi. Tingginya angka kebutuhan kerja di kalangan penduduk Kota Sukabumi, tidak dibarengi dengan ketersediaan kesempatan kerja yang dibutuhkan. Kesenjangan antara jumlah angkatan kerja dengan kesempatan kerja inilah yang kemudian menyebabkan lahirnya pengangguran di kalangan penduduk Kota Sukabumi, baik pengangguran terbuka maupun setengah menganggur. Menurut Undang-undang nomor 13 tahun 2003 tentang ketenagakerjaan, yang dimaksud dengan "pengangguran yaitu penduduk dalam usia kerja yang tidak mempunyai pekerjaan dan sedang mencari pekerjaan"

Dinas Tenaga Kerja Kota Sukabumi adalah satuan kerja perangkat daerah yang memiliki tupoksi melaksanakan urusan Pemerintahan Daerah yang menjadi kewenangan Daerah dan tugas pembantuan yang diberikan di bidang tenaga kerja dan transmigrasi. Dalam melaksanakan tugas pokok Dinas menyelenggarakan fungsi perumusan kebijakan bidang tenaga kerja dan transmigrasi, pelaksanaan kebijakan bidang tenaga kerja dan transmigrasi, pelaksanaan evaluasi dan pelaporan bidang tenaga kerja dan transmigrasi, pelaksanaan administrasi dinas bidang tenaga kerja dan transmigrasi, dan pelaksanaan fungsi lain yang diberikan oleh Walikota terkait dengan tugas dan fungsinya. (Peraturan Walikota Sukabumi Nomor 43 Tahun 2016).

Salah satu upaya yang dilakukan oleh Dinas Tenaga Kerja Kota Sukabumi dalam memberikan layanan publik dibidang penempatan tenaga kerja adalah melalui program bursa kerja, dimana program ini dilakukan oleh Bidang Ketenagakerjaan dan penempatan tenaga kerja yang berkoordinasi dengan sub. bidang BLK (Balai Latihan Kerja) dan beberapa instansi serta perusahaan baik pemerintah maupun swasta atas disposisi Walikota melalui kepala dinas tenaga kerja. Program bursa kerja ini dilaksanakan oleh Dinas Tenaga Kerja Kota Sukabumi, dengan harapan akan mampu menurunkan tingkat pengangguran di kalangan penduduk Kota Sukabumi.

Peraturan Menteri Ketenagakerjaan Republik Indonesia Nomor 39 Tahun 2016 Tentang Penempatan Tenaga Kerja menyebutkan bahwa penempatan tenaga kerja adalah proses pelayanan penempatan yang diberikan kepada pencari kerja untuk memperoleh pekerjaan. Salah satu bentuk pelayanan penempatan kerja yang dimaksud adalah bursa kerja. Pada pasal 1 ayat 16 dikatakan yang dimaksud dengan bursa kerja adalah tempat pelayanan kegiatan penempatan tenaga kerja. Selanjutnya pada pasal 1 ayat 21 menjelaskan pameran kesempatan kerja (job fair) adalah aktivitas mempertemukan sejumlah pencari kerja dengan sejumlah pemberi kerja pada waktu dan tempat tertentu dengan tujuan penempatan.

Dalam Pelaksanaan bursa kerja di Dinas Tenaga Kerja Kota Sukabumi meskipun Pemerintah Daerah telah melaksanakan program ini tersebut dengan semaksimal mungkin, tetapi berdasarkan observasi awal yang peneliti dapatkan di lapangan dan berdasarkan wawancara awal yang peneliti lakukan, terdapat beberapa fenomena yang dilihat oleh peneliti yaitu: kurangnya sosialisasi yang dilakukan oleh Dinas Tenaga Kerja Kota Sukabumi kepada masyarakat mengenai adanya pendaftaran bursa kerja secara online. Dilihat dari jumlah pencari kerja pada tahun 2019 sebanyak 6.871 orang sedangkan yang mendaftar bursa kerja secara online 2.500 orang.

Disposisi belum maksimal contohnya ketika masyarakat membutuhkan informasi mengenai ketenagakerjaan/lowongan kerja, pegawai merespon tidak menaruh perhatian. Sumber daya manusia di Dinas Tenaga Kerja Kota Sukabumi belum memadai, dapat dilihat dari UPT BLK 
hanya dikelola oleh Kepala UPT BLK dan Kasubag. Tata Usaha BLK. Mengenai kekurangan tersebut yaitu kekurangan staff istruktur.

Berdasarkan fenomena masalah tersebut, peneliti merasa tertarik untuk melakukan penelitian yang berjudul: “implementasi kebijakan ketenagakerjaan tentang bursa kerja di Dinas Tenaga Kerja Kota Sukabumi”

Menurut Meter dan Horn dalam Wahab (2015:135) merumuskan implementasi sebagai berikut: "Tindakan-tindakan yang dilakukan baik oleh individual atau pejabat atau kelompok pemerintah dan swasta yang diarahkan pada tercapainya sebuah tujuan yang telah digariskan dalam suatu keputusan kebijaksanaan.

Menurut Mazmanian dan Sabatier dalam Wahab (2015:135) menjelaskan makna implementasi ini dengan menyatakan bahwa : "Memahami apa yang senyatanya terjadi sesudah suatu program dinyatakan berlaku atau dirumuskan merupakan fokus perhatian implementasi kebijakan, yaitu kejadian-kejadian dan kegiatan-kegiatan yang timbul sesudah disahkannya pedoman-pedoman kebijakan publik yang mencakup baik usaha-usaha untuk mengadministrasikannya maupun untuk menimbulkan akibat/dampak nyata pada masyarakat atau kejadian-kejadian."

Dilihat dari definisi diatas, peneliti dapat menginterprestasikan bahwa implementasi adalah sebuah tindakan-tindakan yang dilakukan oleh para pelaksana kebijakan baik pemerintah atau swasta berupa rencana yang sudah disusun secara matang dan terperinci.

Menurut Taufiqurokhman (2014:2) Dalam Kamus Besar Bahasa Indonesia kebijakan diartikan "sebagai rangkaian konsep dan asas yang menjadi garis besar dan dasar rencana dalam pelaksanaan suatu pekerjaan, kepemimpinan, dan cara bertindak (tentang pemerintahan, organisasi, dsb); pernyataan cita-cita, tujuan, prinsip, dan garis pedoman untuk manajemen dalam usaha mencapai sasaran."

Kebijakan menurut pendapat Friedrich dalam Wahab (2015:10) bahwa "Kebijakan adalah suatu tindakan yang mengaruh pada tujuan yang diusulkan oleh seseorang kelompok atau pemerintah dalam lingkungan tertentu sehubungan dengan adanya hambatan-hambatan tertentu seraya mencari peluang-peluang untuk mencapai tujuan atau mewujudkan sasaran yang diinginkan".

Menurut Federick sebagaimana dikutip Agustino mendefinisikan "Kebijakan sebagai serangkaian tindakan/kegiatan yang diusulkan seseorang, kelompok, atau pemerintah dalam suatu lingkungan tertentu di mana terdapat hambatan-hambatan atau kesulitan-kesulitan dan kesempatan-kesempatan terhadap pelaksanaan usulan kebijaksanaan tersebut dalam rangka mencapai tujuan tertentu." (Taufiqurokhman, 2014:2). Maka dengan ini penulis menginterpretasikan bahwa kebijakan adalah tindakan yang berdasarkan peraturan untuk mencapai suatu tujuan yang lebih baik.

Menurut Undang-Undang Republik Indonesia Nomor 13 Tahun 2003 Tentang Ketenagakerjaan menyebutkan bahwa setiap tenaga kerja mempunyai hak dan kesempatan yang sama untuk memilih, mendapatkan, atau pindah pekerjaan dan memperoleh penghasilan yang layak di dalam atau di luar negeri. Penempatan tenaga kerja dilaksanakan berdasarkan asas terbuka, bebas, obyektif, serta adil, dan setara tanpa diskriminasi. Penempatan tenaga kerja diarahkan untuk menempatkan tenaga kerja pada jabatan yang tepat sesuai dengan keahlian, keterampilan, bakat, minat, dan kemampuan dengan memperhatikan harkat, martabat, hak asasi, dan perlindungan hukum. Penempatan tenaga kerja dilaksanakan dengan memperhatikan 
pemerataan kesempatan kerja dan penyediaan tenaga kerja sesuai dengan kebutuhan program nasional dan daerah.

Berdasarkan Peraturan Menteri Ketenagakerjaan Republik Indonesia Nomor 39 Tahun 2016 Tentang Penempatan kerja menyebutkan bahwa bursa kerja adalah tempat pelayanan kegiatan penempatan tenaga kerja.

\section{Metode}

Peneliti menggunakan metode deskriptif dengan pendekatan kualitatif, metode desktiptif ini digunakan untuk mendeskripsikan data, menemukan gambaran fakta-fakta pada saat pelaksanaan sampai pada analisis data. Sedangkan penelitian kualitatif adalah penelitian yang penyajian data yang dikumpulkan terutama dalam bentuk kata-kata, kalimat atau gambar yang dapat memiliki arti daripada sekedar angka atau frekuensi. Metode ini memusatkan pada pemecahan masalah yang bersifat aktual. Sumber data penelitian dengan kualitatif yaitu catatan hasil observasi, wawancara, dan dokumen berupa gambar atau tulisan. (Creswell, 2016) metode kualitatif memiliki pendekatan yang lebih beragam dalam penelitian akademis ketimbang metode kuantitatif. Meskipun prosesnya sama, prosedur kualitatif tetap mengandalkan data berupa teks dan gambar, memiliki langkah-langkah unik dalam analisis datanya, dan bersumber dari strategi penelitian yang berbeda-beda.

Fokus dalam melakukan sebuah penelitian perlu ditentukan. Hal ini dilakukan agar suatu penelitian tidak menyimpang dari tujuan penelitian yang telah ditetapkan. Dalam penelitian kualitatif menyelesaikan masalah dalam penelitian. Untuk itu, fokus penelitian ini adalah mendeskripsikan bagaimana implementasi kebijakan bursa kerja di Dinas Tenaga Kerja Kota Sukabumi dengan menggunakan pendekatan model implementasi George Edwards yang meliputi kriteria Komunikasi, Sumber Daya Manusia, Disposisi dan Struktur Birokrasi.

Subyek dari penelitian ini adalah orang - orang yang dianggap mengetahui dan memahami hal-hal terkait dengan fokus penelitian, sehingga mampu memberikan informasi yang diperlukan. Informan dalam penelitian ini berjumlah 7 informan. Penentuan informan dalam penelitian ini menggunakan menggunakan teknik purposive, yaitu teknik pengambilan sumber data dengan pertimbangan tertentu.

Teknik pengumpulan data dilakukan melalui observasi, wawancara dan dokumentasi. Analisis data yang digunakan berupa mencatat yang menghasilkan catatan lapangan, dengan hal itu diberi kode agar sumber datanya tetap dapat ditelusuri, mengumpulkan, memilah-milah, mengklasifikasikan, mensitetiskan, membuat ikhtisar, dan membuat indeksnya, berfikir, dengan jalan membuat agar kategori data itu mempunyai makna, mencari dan menemukan pola dan hubungan-hubungan, dan membuat temuan-temuan umum.

Teknik pengumpulan data merupakan suatu langkah yang paling strategis melakukan sebuah penelitian. Tujuan utama dalam sebuah penelitian adalah mengumpulkan/mendapatkan data. Jika peneliti ingin mendapatkan data tentunya harus mengetahui terlebih dahulu Teknik pengumpulan data berdasarkan standar-standar data yang ditetapkan. Pada penelitian kualitatif, 
pengumpulan data dilakukan pada kondisi yang alamiah, sumber data yang utama dan dengan adanya teknik pengumpulan data disini lebih banyak pada sebuah observasi berperan serta dengan adanya wawancara yang mendalam. Teknik pengumpulan data yang digunakan peneliti (Sugiyono, 2017) adalah sebagai berikut:

Dalam melakukan sebuah penelitian, langkah pertama yang harus dilakukan yaitu dapat dikatakan sebagai langkah observasi. Mengenai observasi ini peneliti datang dan melihat ke tempat tujuan lokasi penelitian, tetapi peneliti tidak ikut terlibat kepada kegiatan yang sedang berlangsung di tempat tersebut. Tetapi dalam hal lain peneliti ingin mengumpulkan sumbersumber data kepada orang yang mempunyai informasi dengan cara peneliti berterus terang kepada orang yang mempunyai sumber data, bahwa peneliti akan melakukan penelitian di Dinas Tenaga Kerja Kota Sukabumi tersebut.

Dalam penelitian ini, dilakukan wawancara secara terbuka terhadap para informan dengan bertukar informasi dan ide sehingga dapat dikontruksikan kepada suatu topik mengenai fenomena yang ada. Dalam hal ini peneliti melakukan wawancara kepada pihak internal Dinas Tenaga Kerja Kota Sukabumi, Perusahaan dan masyarakat.

Dokumen merupakan sebuah catatan peristiwa atas apa yang sudah berlalu atau dimasa lampau. Dokumen disini dapat berupa tulisan, atau gambar dari pihak yang diperlukan. Dokumen yang berbentuk tulisan berupa sebuah catatan harian, suatu sejarah kehidupan, catatan biografi, peraturan yang telah disepakati, dan kebijakan yang telah dikeluarkan. Dokumen yang berupa gambar yaitu foto, gambar hidup, sketsa dan lain-lain. Dokumen yang berbentuk karya misalnya film, lukisan, desain dan lain-lain.

Analisis data yang digunakan dilapangan dalam penelitian ini adalah dengan menggunakan analisis data kualitatif (Seiddel dalam Moleong, 2016) yaitu: Mencatat yang menghasilkan catatan lapangan, dengan hal itu diberi kode agar sumber datanya tetap dapat ditelusuri. Mengumpulkan, memilah-milah, mengklasifikasikan, mensitetiskan, membuat ikhtisar, dan membuat indeksnya. Berfikir, dengan jalan membuat agar kategori data itu mempunyai makna, mencari dan menemukan pola dan hubungan-hubungan, dan membuat temuan-temuan umum.

\section{Hasil dan Pembahasan}

\section{Komunikasi}

Keberhasilan implementasi kebijakan mensyaratkan agar implementor mengetahui apa yang harus dilakukan. Apa yang menjadi tujuan dan sasaran kebijakan harus ditransmisikan kepada kelompok sasaran (target group) sehingga akan mengurangi distorsi implementasi. Apabila tujuan dan sasaran suatu kebijakan tidak jelas atau bahkan tidak diketahui sama sekali oleh kelompok sasaran, maka kemungkinan akan terjadi resistensi dari kelompok sasaran.

Dalam penelitian ini melalui komunikasi yang dilakukan oleh pihak Dinas Tenaga Kerja Kota Sukabumi dalam menjalankan implementasi bursa kerja melalui sosialisasi. sosialisasi yang dilakukan oleh pihak Dinas Tenaga Kerja Kota Sukabumi kurang lebih kebanyakan melalui media dan online dibandingkan secara langsung kepada perusahaan, masyarakat dan pihak lainnya. 
Dengan adanya sosialisasi yang dilakukan, pendaftaran bursa kerja secara langsung masih banyak dilakukan, sedangkan pihak Dinas Tenaga Kerja Kota Sukabumi sudah memberlakukan pendaftaran bursa kerja secara online, dengan hal tersebut sosialisasi yang dilakukan belum optimal, sehingga kejelasan informasi bagi masyarakat belum tersampaikan, masyarakat juga belum bisa menyesuaikan dengan teknologi yang ada.

Adapun bukti dokumentasi hasil komunikasi baik dari pihak internal, maupun pihak Eksternal dalam pelaksanaan bursa kerja:

\section{Gambar 1}

Komunikasi Internal Berupa Surat Keputusan kepala dinas dalam pelaksanaan bursa kerja

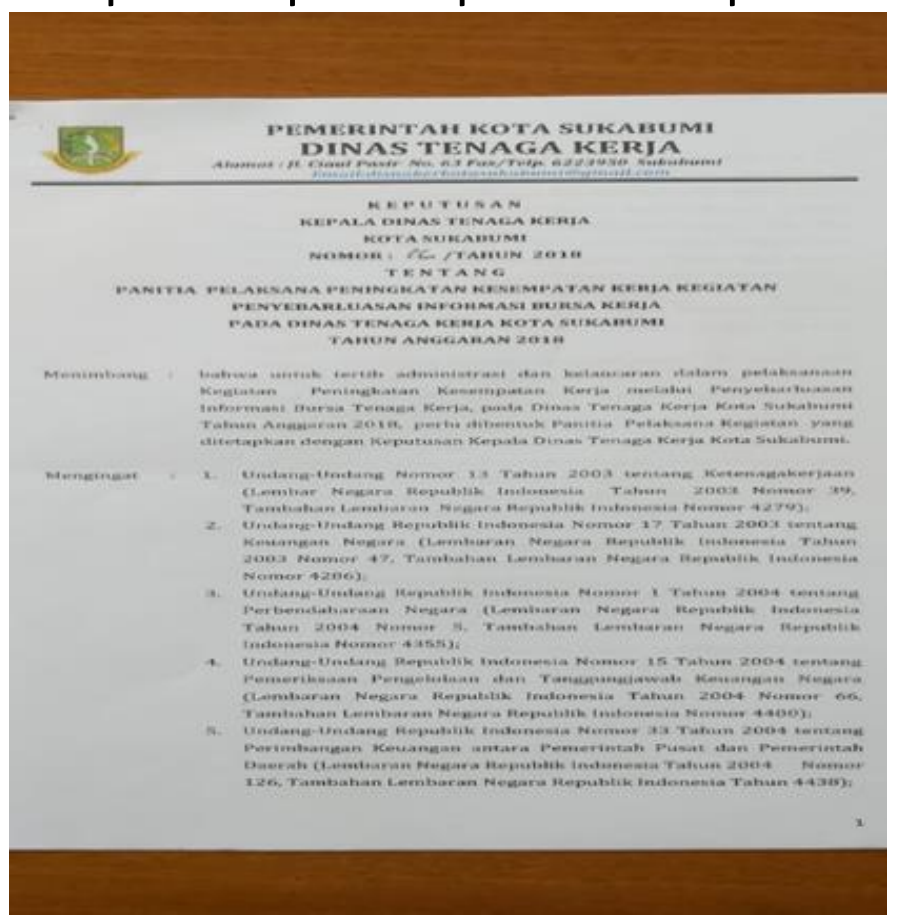

Sumber : Dinas Tenaga Kerja Kota Sukabumi, 2020 
Spirit Publik Volume 15, Nomor 2, 2020

Halaman 158-168

P-ISSN. 1907-0489 E-ISSN 2580-3875

\section{Gambar 2}

Komunikasi Eksternal dengan perusahaan Berupa Surat Undangan

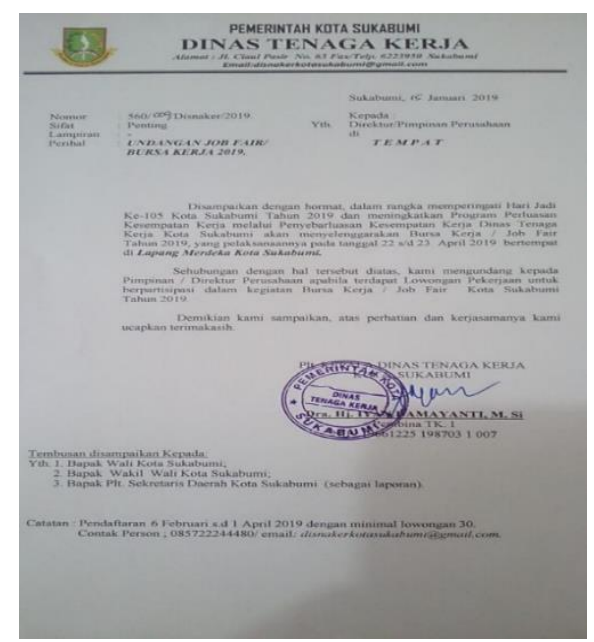

Sumber : Dinas Tenaga Kerja Kota Sukabumi, 2020

Gambar 3

Komunikasi Eksternal dengan masyarakat melalui media sosialisasi pada kegiatan Bursa Kerja 2019

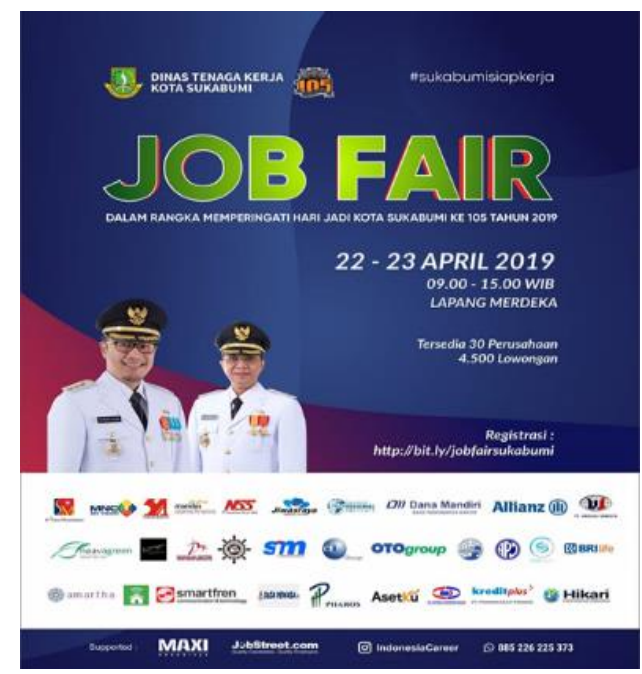

Sumber : Dinas Tenaga Kerja Kota Sukabumi, 2020

2. Sumber daya Manusia

Walaupun isi kebijakan sudah dikomunikasikan secara jelas dan konsisten, tetapi apabila implementor kekurangan sumberdaya untuk melaksanakan implementasi tidak akan berjalan secara efektif. Sumberdaya tersebut dapat berwujud sumberdaya manusia, yakni kompetensi implementor, dan sumber daya finansial. Sumber daya adalah faktor penting untuk implementasi kebijakan agar efektif. Tanpa sumber daya, kebijakan hanya tinggal di kertas menjadi dokumen saja. 
Mengenai sumber daya manusia di Dinas Tenaga Kerja Kota Sukabumi belum bisa memenuhi target ataupun kecukupan staff salah satunya tidak adanya instruktur yang menunjang dalam pelaksanaan kerja untuk masyarakat, tetapi bagaimanapun dalam pelaksanaan tugas pokok dan fungsi masing-masing pegawai harus dapat memaksimalkan kinerja yang diperoleh oleh masing-masing pegawai. Pegawai Dinas Tenaga Kerja Kota Sukabumi juga harus dapat mengikuti teknologi yang modern dengan kemampuan yang dipunya, sehingga segala sesuatu pekerjaan dapat dikerjakan dengan baik dan professional.

Adapun data kebutuhan Instruktur di Dinas Tenaga Kerja Kota Sukabumi dapat dilihat pada tabel berikut:

Tabel 1.

Data Kebutuhan Instruktur

\begin{tabular}{|c|c|c|c|c|c|}
\hline \multicolumn{6}{|c|}{ DATA KEBUTUHAN INSTRUKTUR } \\
\hline & UNIT KERJA : & UPT BLK DISNAKER KOTA SUKABUMI & & & \\
\hline NO & Kejuruan & Sub Kejuruan & $\begin{array}{l}\text { Jumlah } \\
\text { Intruktur/ } \\
\text { existing } \\
\text { (org) }\end{array}$ & $\begin{array}{l}\text { Jumlah } \\
\text { Kekurangan } \\
\text { Instruktur } \\
\text { (org) }\end{array}$ & Keterangan \\
\hline 1 & Welding & Teknik Pengelasan & 0 & 1 & \\
\hline \multirow{2}{*}{2} & \multirow{2}{*}{ Automotif } & - Motor & 0 & 1 & \\
\hline & & - Mobil & 0 & 1 & \\
\hline 3 & Tata Boga & & 0 & 1 & \\
\hline \multirow[t]{3}{*}{4} & Menjahit/Tata Busana & - Operator Quikment & 0 & 1 & \\
\hline & & $\begin{array}{l}\text {-Menjahit Pakaian Wanita dan Anak } \\
\text { (MPWA) }\end{array}$ & 0 & 1 & \\
\hline & & -Menjahit Pakaian Pria (MPP) & 0 & 1 & \\
\hline & & & & & \\
\hline & & & & & \\
\hline & & & \multicolumn{3}{|c|}{ Kepala Dinas Tenaga Kerja } \\
\hline & & & \multicolumn{3}{|c|}{ Kota Sukabumi } \\
\hline & & & & & \\
\hline & & & & & \\
\hline & & & \multicolumn{3}{|c|}{ Drs.H. DIDIN SYARIFUDIN, M.Si } \\
\hline & & & \multicolumn{3}{|c|}{ Pembina Tk. I } \\
\hline
\end{tabular}

Sumber: Dinas Tenaga Kerja Kota Sukabumi, 2020 


\section{Disposisi}

Disposisi adalah watak dan karakteristik yang dimiliki oleh implementor, seperti komitmen, kejujuran, sifat demokratis. Apabila implementor memiliki disposisi yang baik, maka dia akan dapat menjalankan kebijakan dengan baik seperti apa yang diinginkan oleh pembuat kebijakan. Ketika implementor memiliki sikap atau perspektif yang berbeda dengan pembuat kebijakan, maka proses implementasi kebijakan juga menjadi tidak efektif.

Dalam kriteria disposisi yang diberikan berupa sikap dan pelayanan kepada pihak-pihak terkait seperti masyarakat, perusahaan dan lainnya, dengan adanya sikap dan pelayanan yang baik dapat menunjang keberhasilan disposisi pegawai dengan mengutamakan tugas pokok dan fungsi yang diberikan. Karena capaian kinerja pegawai sendiri ditentukan oleh standar pekerjaan yang dijalankan dalam pencapaian wewenang dan komitmen yang diberikan dapat dijalankan walaupun tidak sesuai dengan bidang masing-masing pegawai, tetapi dalam pelaksanaan bursa kerja melibatkan seluruh internal pihak Dinas Tenaga Kerja Kota Sukabumi. Tetapi mengenai disposisi ini seharusnya ketika pada saat pelaksanaan bursa kerja di lapangan, adanya penambahan panitia pelaksana, sehingga masyarakat tidak merasa bahwa pihak para pelaksana acuh tak acuh ketika masyarakat membutuhkan informasi.dengan begitu dengan adanya kerjasama antar pegawai dalam menjalankan tugas yang diberikan dapat menunjang keberhasilan implementasi.

\section{Struktur Birokrasi}

Struktur organisasi yang bertugas mengimplementasikan kebijakan memiliki pengaruh yang signifikan terhadap implementasi kebijakan. Salah satu dari aspek struktur yang penting dari setiap organisasi adalah adanya suatu prosedur operasional yang standard (standard operating procedures atau SOP). SOP menjadi pedoman bagi setiap implementor dalam bertindak. (Agustino, 2017) SOP adalah suatu prosedur atau aktivitas terencana yang memungkinkan para pelaksana kebijakan seperti aparatur, administratur, atau birokrat) untuk melaksanakan kegiatankegiatannya sesuai dengan standar yang telah ditetapkan.

Mengenai struktur birokasi pada Dinas Tenaga Kerja Kota Sukabumi sudah efektif, terstruktur dengan baik, tersusun sesuai dengan standar operasional prosedur yang berlaku pada setiap pelaksanaan kegiatan, dan juga sesuai dengan standar operasional tata kerja yang tercantum dalam Peraturan Walikota 43 tahun 2016.

\section{Penutup}

Berdasarkan hasil penelitian yang telah dideskripsikan sebelumnya mengenai implementasi kebijakan bursa kerja di Dinas Tenaga Kerja Kota Sukabumi pada umumnya sudah berjalan dengan baik, dilihat dari 4 kriteria penting dari proses implementasi kebijakan bursa kerja sebagaimana yang dikemukakan oleh Edward, dapat diambil kesimpulan yaitu sebagai berikut :

Kriteria komunikasi yakni dapat dilihat dari seberapa tanggapnya pihak-pihak yang terlibat dalam pelaksanaan kegiatan bursa kerja, dalam komunikasi sudah berjalan dengan baik meskipun 
belum optimal dikarenakan pentingnya sosialisasi yang harus dilakukan lebih baik lagi kepada masyarakat, perusahaan. Dikarenakan masih terdapat masyarakat yang belum mengetahui adanya pendaftaran bursa kerja secara online.

Kriteria sumber daya manusia utama dalam implementasi kebijakan adalah staf. Dinas Tenaga Kerja Kota Sukabumi dalam mengatur sumber daya manusia yang ada belum memadai, dikarenakan kekurangan staff sehingga dalam proses pelaksanaan kegiatan kurang efektif. Salah satunya tidak adanya instruktur, kekurangan staff ini dapat memperlambat proses implementasi.

Kriteria Disposisi Dinas Tenaga Kerja Kota Sukabumi sikap dan pelayanan yang diberikan sesuai dengan tanggungjawab para pegawai, komitmen dan kedisiplinan sudah tercantum dalam tugas pokok dan fungsi masing-masing pegawai, hanya saja ketika pada saat pelaksanaan bursa kerja dilapangan, adanya penambahan panitia pelaksana sehingga masyarakat tidak merasa bahwa pihak para pelaksana acuh tak acuh ketika masyarakat membutuhkan informasi.

Mengenai kriteria struktur birokrasi pada Dinas Tenaga Kerja Kota Sukabumi seperti adanya Standar Operasional Prosedur (SOP) pada setiap kegiatan sudah optimal, para pegawai melaksanakan tugas kegiatannya sesuai standar yang berlaku dan mengacu kepada Peraturan Walikota nomor 43 Tahun 2016.

Adapun saran yang dapat peneliti berikan yaitu:

Diharapkan pihak Dinas Tenaga Kerja Kota Sukabumi dapat mengadakan bursa kerja setiap tahunnya minimal dua kali dikarenakan banyaknya permintaan lowongan kerja dari perusahaan dan antusiasnya masyarakat untuk mencari pekerjaan.

Hendaknya pihak Dinas Tenaga Kerja Kota Sukabumi Ketika sebelum diadakannya kegiatan bursa kerja, diumumkan terlebih dahulu lowongan pekerjaan, kualifikasi dan persyaratannya dari perusahaan apa saja kepada masyarakat, sehingga masyarakat sudah mempersiapkan diri dan mengetahui rencana yang akan dilakukan Ketika mendatangi kegiatan bursa kerja yang berlangsung.

Hendaknya pihak pemerintah Kota Sukabumi Khususnya Dinas Tenaga Kerja Kota Sukabumi dapat menjalin kerjasama yang lebih baik dengan mendatangkan instansi-instansi atau perusahaan-perusahaan besar dalam proses pelaksanaan bursa kerja.

Diharapkan pihak Pemerintah Kota Sukabumi khususnya Dinas Tenaga Kerja Kota Sukabumi dapat melihat kebutuhan pekerjaan masyarakat dalam satu wilayahnya terlebih dahulu, jangan sampai ketika adanya pelaksanaan bursa kerja, penempatan kerja untuk masyarakat Sukabumi sedikit dibanding masyarakat luar Sukabumi atau luar daerah.

\section{Referensi}

Abdul Wahab, Solichin. (2015). Analisis Kebijakan dari Formulasi ke

Penyusunan Model-Model Implementasi Kebijakan Publik. Jakarta, PT Bumi Aksara. 
Agustino, Leo. (2017). Dasar-Dasar Kebijakan Publik. Bandung, Alfabeta, CV.

Creswell, Jhon W. (2016). Research Design Pendekatan Kualitatif, Kuantitatif, dan Mixed. Yogyakarta, Pustaka Pelajar.

Moleong, Lexy. (2017). Metode Penelitian Kualitatif. Bandung, PT Remaja Rosdakarya.

Peraturan Menteri Ketenagakerjaan Republik Indonesia Nomor 39 Tahun 2016 Tentang Penempatan Tenaga Kerja.

Peraturan Walikota Sukabumi Nomor 43 Tahun 2016 Tentang Kedudukan, Susunan Organisasi, Tugas Pokok, Fungsi, Dan Tata Kerja Dinas Tenaga Kerja.

Sugiyono. (2017). Metode Penelitian Kuantitatif, Kualitatif, dan R\&D. Bandung, Alfabeta, CV.

Taufiqurrakhman. (2014). Kebijakan Publik Pendelegasian Tanggungjawab Negara Kepada Presiden Selaku Penyelenggara Pemerintahan. Jakarta, Fakultas Ilmu Sosial Dan llmu Politik Universitas Moestopo Beragama (Pers). Retrieved from https://www.moestopo.ac.id/wpcontent/uploads/2016/08/Kebijakan-Publik Oleh-Dr.Taufiqurokhman.-M.Si.pdf

Undang-Undang Ketenagakerjaan Nomor 13 Tahun 2003. 